CRÍTICA, Revista Hispanoamericana de Filosofia

Vol. XXI, No. 63 (diciembre 1989): 33-58

\title{
RULES, COMMUNITIES AND JUDGEMENTS *
}

JosE L. ZALABARDO

Universidad de Michigan

Ann Arbor

It is widely acknowledged as one of the main insights of Wittgenstein's so-called rule-following considerations that since every rule can be variously interpreted and there is no such thing as checking the correctness of an interpretation against the rule itself other than by means of another interpretation, the application of a rule is ultimately an ungrounded act; we simply follow our inclinations to act in a certain way, and in so doing constitute, at each step, the pattern of correctness we illusorily believe ourselves to be following.

Of course, this thought by itself doesn't offer an alternative picture of normativity. It rather casts down a challenge on the very coherence of the notion, since we need rules to be normative with respect to behaviour, to the inclination to apply them in a certain way. If correctness is defined in terms of an inclination it just makes no sense to speak of the correctness of the defining inclination.

It has become a standard reaction to this situation to 'go so-

- This paper is based on some sections of my MPhil thesis, written at the University of St Andrews under the supervision of Crispin Wright. I want to thank him for his extremely valuable support. I also want to thank Simon Biackburn, who made very useful comments on an earlier version of this paper. I am also grateful to Allan Gibbard, Nicholas White and Stephen Yablo for their interesting comments and criticism. The work leading to this paper has been supported by the Diputación General de Aragón (Spain). 
cial' - to claim, namely, that it is against the communal verdicts concerning what is to count as a correct application of a rule that each individual's inclinations can be assessed. But this proposal faces trouble as soon as we consider the extent to which the notion of normativity is a constitutive element of the notion of objective judgment. As Simon Blackburn puts it,

If my community all suddenly started saying that $57+68=5$, this fact does not make me wrong when I continue to assert that it is 125 . I am correct today in saying that the sun is shining and daffodils are yellow, regardless of what the rest of the world says. Obviously any solution to these problems must avoid the disastrous conclusion that it is part of the truth-condition of any judgment that a community would make it (unless of course the judgment is itself not about the sun and daffodils and so on, but about the community). ${ }^{1}$

The problem is of course not one that communal responses create. It is rather a corollary of the rule-following considerations themselves that since there is no way to make sense of what it would be for an object to be - say - red or square, other than on terms of someone's inclinations, the having of these features can hardly be thought of as an objective matter. It might be argued that the lack of objectivity of the notions of squareness or redness is wholly due to their linguistic or conceptual component, so that a core of hard facts could still be isolated from the inclination-dependent-aspects. But there are important reasons to wonder about the coherence of this pre-linguistic, pre-conceptual notion of fact. Moreover, since the facts we deal with do suffer this linguistic or conceptual dependence, it is hard to see what the notion of a pre-conceptual fact would be good for. Its usefulness relies on the possibility of bringing apart the conceptual and the wordly components of the truth of a judgment (what the world would have to be like in order to make the judgment true and what the world is actually like in the situations in which we hold the judgment true); but p. 294.

1 Simon Blackbum, “The Individual Strikes Back”, Synthèse 58 (1984), 
this possibility depends in turn on the availability of the notion of an objetive pattern that the rule-following considerations undermine. The communal accounts do not solve this problem, but rejecting them would not make the problem disappear —we would still need an account of the notion of objective judgment which does not make use of the notions that the rule-following considerations have proven unavailable.

In this paper I first consider how the communal account put forward by Kripke fares as an explanation of the notion of rule following. Then I go on to argue for an alternative picture of the nature of rules and discuss its consequences for the notion of objectivity.

\section{Kripke's Sceptical Solution}

Kripke, in his Wittgenstein on Rules and Private Language, ${ }^{2}$ has offered a very forceful argument to show how a reflection on the notion of normativity undermines our conception of meaning and other intentional notions. In the first chapter of the book, he develops the argument in the form of a sceptical challenge: a sceptic challenges my knowledge of what I meant in the past by a certain expression, of how the expression, as I understood it in the past, should be applied in a present case. The sceptic's challenge consists in showing that all the facts that I may adduce as constituting my having attached a certain meaning to the expression in the past are compatible with an alternative hypothesis concerning my past understanding of the expression. The immediate conclusion is that nothing in my behaviour or in my mental life constitutes my attaching a certain meaning to the expression instead of another one. Hence there is no fact of the matter as to whether I mean some thing or other by an expression, i.e., given two possible meanings of

${ }^{2}$ Saul Kripke, Wittgenstein on Rules and Private Language, Blackwell, Oxford, 1982. [Wittgenstein: reglas y lenguaje privado, trad. de Alejandro Tomasini, UNAM, México, 1989.] 
an expression, it is not fixed at a certain moment which of them I attach to it.

This might be a serious problem, but it is not the problem Kripke is ultimately aiming at with his argument. In fact the sceptic's challenge is admittedly "merely a dramatic device"3 to help make the problem more vivid and to avoid problems concerning use and mention and present and past language, that is, in order to be able to express the paradox at all. If the sceptic wins, the outcome is not that it is indeterminate which meaning I attach to a certain expression. Rather, "of course, ultimately, if the sceptic is right, the concepts of meaning and of intending one function rather than another will make no sense". 4

The result does not concern an indeterminacy as to which rule is being followed, but the notion of rule itself. By means of an analysis of what goes on in a subject when he follows a rule, we arrive at the conclusion that in so doing all he does is to follow his blind, ultimately unjustified inclination to act in a certain way. The notion of rules as normative standards which determine the correctness of each of their possible applications is just an illusion. There is nothing we are being faithful to with a certain application. In fact there is nothing we apply when we act in a certain way. We just act according to our inclinations. But this is precisely what goes on in us when we are following no rule at all.

It is important to bear in mind that this is the conclusion that Kripke has arrived at in the first chapter of his book if we are to assess the merits of the solution he offers in the second chapter. Kripke labels his solution 'sceptical'. A sceptical solution to a sceptical problem consists of two steps. ${ }^{5}$ First, it is conceded that the sceptic's negative assertions are unanswerable. Then,

\footnotetext{
3 Id., p. 10.

4 Id., p. 13.

5 See Id., p. 66.
} 
in the second step, it is shown that the justification the sceptic has proved to be unavailable was not required after all.

As the first step of his sceptical solution to the sceptical problem concerning rule-following, Kripke acknowledges that our discourse about intentions, understanding and meaning is not factual, it lacks truth conditions, there are no facts corresponding to our apparently factual assertions. As the second step he describes the assertibility conditions of such assertions, the conditions under which we consider them justified. I want to question the extent to which Kripke's 'solution' solves at all the problem it was meant to solve.

Kripke's sceptical solution consists in describing the conditions under which we consider as justified the claim that a subject's (ungrounded) inclinations are to be taken as right or wrong. This certainly solves the immediate problem that the sceptic's challenge posed. If it is indeterminate which meaning a speaker attaches to an expression, then there is no fact of the matter as to whether a new application of the expression accords with his previous understanding of it, and then whichever way he decides to go on there will be no conflict - or accord-with his past intentions. If this was the problem, Kripke's solution is quite pertinent: it is communal agreement what decides whether a new application will be taken as correct. The lack of an objetive criterion to choose between the alternatives is made up for by this consensus in the community of speakers. Moreover, the practice he describes provides not only the conditions under which each single response is to be accepted as correct, but also the conditions under which a speaker's inclinations are to be taken in principle as reliable, as normally producing the responses that will agree with the communal standard. In this way a speaker who has passed the tests of rule-following competence can be reasonably confident that the responses he feels inclined to give are the 'right' ones, without waiting for the community's verdict over each single case.

But the real problem was not one of choosing between alter- 
natives, but rather about the very notion of what it is to mean something by an expression. To describe how our inclinations can be considered 'wrong' even when an objetive standard of correctness has been found to be missing may well be a solution to the former problem, but it is hard to see what kind of illumination the latter receives.

The problem is that we have found that the notion of content is normative in the following sense: that whatever constitutes the content that a speaker attributes to an expression it must contain a determination of which states of affairs 'fit' the content, thus making the expression, as it is meant, applicable to them. The states of affairs so determined will constitute the identity conditions for the content in question. Moreover this determination must be something in which the speaker has nothing to do, because it is with respect to his inclination that meaning has to be normative.

But the sceptical paradox has shown that the idea of such advanced determination is a myth. Thus the result is not merely that there is no fact as to when a speaker attributes a content to an expression, but rather that we lack an adequate notion of content. Not only do we ignore the conditions in which content ascriptions should be asserted. Also, and more importantly, we have no idea of what these ascriptions may mean. They are supposed to contain a notion of the conditions under which the content will fit the world - but this notion has proven illegitimate.

The question now is whether Kripke's description of the assertibility conditions of content ascriptions could provide the meaning of the ascriptions, so that both problems are solved at once. In order to answer this question we must consider what, according to Kripke, the content ascriber can do. Clearly he cannot provide the objetive determination of the conditions of fit that constitutes content according to the picture that the sceptical paradox undermines. All he can provide is his own blind inclination to act as a pattern of correctness for the speaker's responses. But if this is what content ascriptions come to, 
it amounts to saying that the conditions of fit that have been ascribed are determined by the ascriber's impression that a fit has occurred. Therefore, if this is the only sense we can make of the determination of conditions of fit that constitutes content, all judgments would collapse into judgments about the ascriber's (or the whole community's) inclinations to consider certain situations as in some respect similar to each other.

Thus, if we take Kripke's description of the assertibility conditions of content ascriptions as providing the meaning of the ascriptions, the notion of content that would arise would be hardly recognisable. Our fellow speakers' inclinations would be the subject matter of all our judgments; there would be no such thing as saying how things stand in the world - that the sun is shining, daffodils are yellow or $57+68=125$.

If on the other hand we acknowledge that a description of assertibility conditions does not provide the meaning of content ascriptions we may wonder what does. As far as I can see, Kripke gives us no help in this respect. Thus we seem forced to admit that he describes the conditions under which something is attributed, but provides no indication of what the content of the attribution might be. But this amounts to saying that the main problem posed by the sceptic - that the concepts of meaning and intending one function rather than another make no sense- remains unsolved.

In Kripke's own presentation of his solution in the second chapter of his book there are some indications that give reasons to think that he has forgotten that the sceptical challenge was "a merely dramatic device", and that the real problem arrived at was not one of lack of determination between competing alternatives. When he presents the second step of his sceptical solution he writes that "it is important to realize that we are not looking for necessary and sufficient conditions (truth conditions) for following a rule, or an analysis of what such rule-following 'consists in'. Indeed such conditions would con- 
stitute a 'straight' solution to the sceptical problem, and have been rejected". 6

But it is not obvious at all in what sense a sceptical solution excludes an analysis of what rule-following consists in. What a sceptical solution requires is an account of why the justification shown by the sceptic to be untenable is after all not needed. But now it is hard to see which element of Kripke's solution provides this account. If the problem was one of choosing between alternative meanings, Kripke shows successfully that this problem can be solved without recourse to the justification provided by an objetive standard of correctness. Communal verdicts can make up for the unavailability of an objective standard. But if the problem was that the concept of meaning makes no sense, then what a sceptical solution requires is an account of why it does make sense, despite the unavailability of the notions undermined by the sceptic. It seems that providing this account would require to show 'what sense it makes', and as we have seen the description of assertibility conditions provided by Kripke fails to show this.

The fact is that showing that the justification for the concept of meaning that the sceptic undermines is not needed requires an account of what meaning consists in which does not make use of the idea of an objetive standard of correctness. If this is dismissed as 'straight' we are left with no indication of how a 'real' sceptical solution can manage to show the dispensability of the unavailable justifications. Describing the circumstances under which we attribute understanding to a speaker does not help in the slightest to show that no justification for these attributions is needed.

To sum up the point I have been trying to make we may consider the dilemma we face in the interpretation of Kripke's (Wittgenstein's) solution. Either his explanation of the conditions under which we attribute to a speaker understanding of

${ }^{6}$ Id., p. 87, my italics. 
an expression constitutes also an account of what it is that we thereby attribute to a speaker or it does not. If it does, then attributing a certain meaning to an expression consists in using it in ways that the speaker's linguistic community is inclined to consider as correct. But then we seem to be left with no means to make sense of the distinction between judgments about the world and judgments about my fellow speakers' dispositions, which we need in order to have an adequate notion of content.

If, on the other hand, Kripke's account of the conditions under which we attribute understanding to a speaker is not meant as an account of the contents of these attributions, then it is difficult to see how this proposal offers a solution to the problem he has posed in the first chapter of his book. It certainly adds to the plausibility of Kripke's account that the meaningfulness of language, in a sense, does not need a justification, quite simply because language is meaningful, because the sceptical paradox is self-defeating. It is only in this sense that the justification shown by the sceptic to be untenable can be thought of as dispensable. But then no sceptical solution is required to show this. The problem is that if we take the way of a sceptical solution and admit the sceptic's negative conclusions we are left with the apparently contradictory situation that no fact can constitute something which we perceive as being the case. No fact constitutes the difference between a linguistic expression and a meaningless sequence of noises - so much as Kripke's own conclusion-, and unless we are ready to give up the distinction altogether, and consider discourse about meaning as metaphorical or simply mistaken, Kripke's solution cannot be accepted as such, and a new attempt must be made to render the situation intelligible.

The suggestion I want to develop in the rest of the paper attempts to take seriously the negative points that follow from the sceptical paradox for the notion of content - that is, any constraint we succeed in imposing upon the world must be ultimately constituted by the inclinations to act we share as a 
group. And the only way to assume this result, to provide a real sceptical solution, is to realize that if we want to make sense of the judgments that the sun is shining, that daffodils are yellow, or that $58+67=125$, we must admit that the notions of what it is for the sun to be shining, for daffodils to be yellow, or for $58+67$ to equal 125 must be somehow constituted by those shared inclinations.

We cannot deny that there are meaning facts on the grounds that nothing could fit our philosophical preconception of what a meaning fact should be - this would amount to leaving the main problem unsolved. It seems more appropriate to change the philosophical preconception and assume that the notion of correctness generated in the process of communal interaction described by Kripke constitutes the only notion of meaning we are entitled to. As we have seen if that is what meaning facts are, it follows that our notion of objectivity cannot be kept, that we need an alternative conception of what it is for the sun to be shining or for daffodils to be yellow. This is an important price, but so much seems to be required by a sceptical solution, since our notion of objectivity rests on a notion of content that the sceptical paradox has proven unavailable.

\section{Rules and Interpretation}

The result of the sceptical paradox is that no further fact, in addition to what one does, can constitute the difference between a piece of rule-governed behaviour and a blind inclination to act in a certain way; that is, what one does when following rules is precisely to act in the way one is blindly inclined to act. This could be seen as the end of the question: we were looking for a difference where there is actually none, hence we are wrong and in fact following a rule, speaking a language, comes to nothing but acting in a certain way and uttering some vocal noises. But it is important that this cannot be our conclusion. There is a difference between, on one hand, perceiving the vocal noises 
produced by someone and even acknowledging that they accomplish some pattern of correctness, and, on the other hand, understanding what he says. But if the sceptic is right in that there is nothing going on in a speaker whose utterances are meaningful in addition to what goes on in another speaker who just utters some noises whenever he feels compelled to do so, then it seems clear that the fact that there is such difference for us must be based on something we contribute in our interpretative approach to some pieces of behaviour as rule-governed or some utterances as meaningful.

If nothing going on in the subject constitutes the difference between his following a rule wrongfully and his following a different rule rightly, it is our responsability to establish this difference when we interpret his behaviour, and our attribution is not answerable to anything going on in the subject, but rather constitutes his following the rule we attribute to him. He cannot be said to be following a standard of correctness for his inclinations, since all he can possibly follow is his inclinations. But an independent standard of correctness is precisely what we need in order to be able to explain his behaviour as rule-governed: a notion of what the rule commands independent of what he believes it commands, criteria of identity for the rule other than the way it is applied. This is what we attribute to rule-followers but has been found to be missing. This constitutes a mistake only if we take our attribution as a hypothesis concerning what is the case with the subject. But if we take it rather as constituting the fact it attributes we shall start to see the notion of rule-following in what $I$ take is its real dimension.

When a subject follows his inclinations to perform a certain action there is nothing going on in him that makes the difference between his following a certain rule correctly and his following a different rule incorrectly. This amounts to saying that when someone is following a rule nothing of what he does constitutes his doing so. But when we interpret him as following a certain rule we do have a notion of what the rule he is follow- 
ing commands in each case, and it is in virtue of this notion that we can make sense of his behaviour being right or wrong, in terms of the response that, according to the rule, he should have given. This standard of correctness is what we contribute when we interpret him as following a certain rule. According to it the notion of misapplication could be defined and it becomes meaningful what elements of his behaviour constitute mistakes and to describe the conditions under which he would apply the rule correctly. It is only our normative hypothesis which gives a content to the distinction between his following wrongfully the same rule we are following and on the other hand his following quite correctly a different rule. Prior to our interpretation this distinction is just not there.

But it may seem that if the problem originated in the unavailability of the kind of normative object suitable to perform the role of a standard of correctness, it cannot be solved by just saying that it is the interpreter who has a grasp of that object. This is a quite legitimate worry to have, but it does not affect what I am suggesting here. My suggestion is not that the interpreter has access to some objective standard of correctness according to which he assesses the subject's behaviour. What the interpreter does when he takes a subject as following a certain rule is to take his own blind inclination to act as a standard of correctness for the subject's behaviour. Against his own blind response the subject's behaviour can be assessed for correctness, the notion of misapplication can be defined and hence the rule someone is following acquires criteria of identity which are independent from what he actually does. Only in this way the possibility of rule-following can be accounted for without recourse to chimerical notions which hide, rather than clarify, the real nature of the problem.

\section{Objectivity}

Now I would like to sketch the notion of objectivity which arises 
from this picture of rule following. What the rule following considerations come to is that the pattern which constitutes the content of our judgments cannot be thought of as an objective entity which extends of itself to every possible case independently of anyone's opinion about what its correct application is. According to the present proposal it is certainly independent of me as a speaker, but not of those who interpret my speech as meaningful. For them the content of my expression is not an independent object of which they have a grasp and about which they could always be wrong, something in terms of which their responses are defined as right or wrong, as following the same pattern or as unnoticedly involving change in their original understanding of my expression.

For the interpreters of my expressions the patterns they use as interpretative hypotheses are absolute, in the sense that there is no further fact that they could get wrong. That I am following a certain pattern against which my application of the expression could be wrong, a pattern in virtue of which my vocal noises become meaningful, content-conveying linguistic expressions, is not a previous fact they try to reflect with their hypothesis; rather; the fact that I am following that pattern is constituted by their hypothesis. It is only in terms of it that content can be given to the notion of change or stability in my understanding of an expression, that the notion of sameness of application can be defined; the alternative is to make my subjective impression that I am applying the expression in the same way true by definition, thereby emptying my judgments of any objective content whatsoever.

But note that the absoluteness of their interpretative hypotheses is more radical than what follows from the fact that they constitute the pattern of correctness for my utterances. For their interpretation does not consist in attributing to my understanding a pattern of correctness which, although it is not answerable to any previous fact about me, nevertheless has its own criteria of identity independently of the interpreter's opinion. If that 
were the case, they still could be said to be wrong, in the sense that they do not grasp correctly which applications the understanding they attribute to me commands. But the interpreters themselves do not have what has been found to be missing in the speakers. They do not have grasp of a pattern which extends of itself, in terms of which what they take as 'going on in the same way' could be said to be wrong. What prompted this whole account was precisely the unavailability of that notion, the idea that the notion of sameness can only be made sense of in terms of someone's impression of sameness, and hence not everyone's impressions can (in principle) be said to be right or wrong in terms of an independent pattern.

The thought is rather that the interpreter's subjective impression of sameness is the standard against which mine is to be taken as right or wrong. The interpreter's impression follows no objective pattern, it is a mere ungrounded inclination to act in a certain way and to take this way of acting as uniform. It has nothing to do with an interpretation, because if it were the result of one it would be just one of the possible ways of interpreting it; nor is it a mere extrapolation from his previous responses, which could also be carried out in infinitely many ways. It is just a way of acting, completely undetachable from him. He does this and that and comes to this result, as a matter of fact. All he can do to communicate his inclinations is to give examples and explanations, but all these can be misinterpreted. They do not determine what the next application will be. They can at most point at a certain inclination of the person trying to understand the examples or explanations which is similar, as a matter of fact, to that of the interpreter. The process of interpretation consists in hardening the fact that he comes to this result into the rule that $I$ should come to it, that what the state of affairs should be in order for my understanding of the expression to command that result is precisely a state of affairs in which the interpreter, as a matter of fact, arrives at that result.

But then Blackburn's objection to communal accounts seems 
to apply no less to the present proposal: if the conditions in which my judgment is true are the conditions in which my interpreter is inclined to give a certain ungrounded response, what kind of objectivity can I attribute to my judgment that something is the case over and above the fact that my interpreter is inclined to accept as correct my judgment that something is the case? Let's see where we are. First, we know that the normative nature of content cannot be appropriately accounted for only in terms of the subject's inclinations, since once we take the subject's impression of sameness as the criterion of sameness objective judgments collapse into judgments about subjective inclinations. Second, if the rule following considerations are to be taken seriously we cannot recur either to an objective pattern in terms of which the correctness of the application of rules could be defined. In these circumstances there is no way out other than assuming the constitutive role played by the interpreters' inclinations with respect to the notion of content. But then the problem arises that there doesn't seem to be a way of taking interpreters as constituting content without having them also rule what is the case in the world.

All we could say is that we are not making the interpreters' opinion true by definition because an interpretative hypothesis in the sense described is not an opinion. It is nothing like a content-conveying linguistic expression. It lacks the independent standard of correctness that would give content to it. It is just an ungrounded inclination to act in a certain way, and cannot be said to be right or wrong, for what it would be for it to be right or wrong has simply not been defined.

But this account is likely to be thought unsatisfactory. Even granting that it is not the interpreter's opinion which constitutes the objective state of affairs in question - because it is not an opinion at all - it seems that the notion of objectivity somehow requires that the interpreter's inclinations are as much subject to the possibility of error as my own are. It is required that the notion of objectivity is not subject to the same arbitrariness that 
the interpreter's inclinations are, because after all there is the possibility that when my inclinations and my interpreter's diverge at some point, we may want to describe this as his having deviated from the sense of sameness at which we both aimed. This divergence could come about, for example, after his brain has been seriously damaged as a result of an accident, or whenever he has had too much to drink.

But let's see clearly what this amounts to. If we want the possibility to be open that his responses are rendered wrong in the light of my inclinations, then what is required is that the process of interpretation is reciprocal, that I interpret his expressions at the same time that he interprets mine, so that whenever a conflict arises both his responses and mine are candidates for rejection. Only in this way can a notion of content arise in terms of which both his and my blind inclinations become opinions, descriptions of states of affairs which are equally capable of being right or wrong.

Of course it is a contingent fact that this process of reciprocal interpretation can be carried out in a particular case. There must be a basic agreement that we aim at the same regularity, that in case of conflict one of us must be wrong; that is, we must each decide to take each other as speaking the same language as we ourselves. But this in turn is possible only if there is some uniformity in our responses, that is, if after similar sequences of training and exposure to similar examples and explanations what we regard as 'to go on the same way' is in a relevant number of cases the same for all of us. Once this agreement has come about, what we as a matter of fact are inclined to do is reciprocally taken as a standard of what the others should do. It is this standard of correctness imposed upon my behaviour by the rest of the members of my community of interpretation that turns my behaviour into a rule-governed one and my utterances into content-conveying linguistic expressions. In this way there is a notion of what an object should be like in order to be red or square, or a notion of what result constitutes the 
multiplication of two numbers, which is independent of anyone's single-handed inclination, but which is constituted by the inclinations we share as a group.

That content is so constituted, in terms of our inclinations, has clear consequences for the corresponding notion of reality. Now it is the communal result of this interpretative interaction, the resulting communal standard, which constitutes the fixed point of reference in terms of which sameness is defined, and stability and change can be made sense of. It is in virtue of it that two objects have the same or different colours, the same or different number of corners, or that an object changes its size, colour, shape, etc. That the result is an objective world is something that can hardly be denied. Given that it is what we deal with as objective, the claim that it is not objective would have to be supplemented with a positive account of what is, as Wittgenstein often reminds us in On Certainty.

But this objectivity depends on the subject in a clear sense. The pattern in terms of which it is constituted is not such that, once arrived at, it can be detached from us and extended spontaneously. There is no single correct interpretation of what we do that would be the continuation of the pattern our inclination to act constitutes. That a certain result is the multiplication of two numbers is undetachable from the brute fact that when we do this and that with them we arrive at that result, and this in a completely ungrounded way. When there are no more beings on the Earth who have a mastery of this technique, of doing this and that and arriving at a certain result, the question of what the result of a certain multiplication is will simply lack sense. The same goes for all our concepts. If the world is something whose objects are what they are independently of us, the very rossibility of this notions depends, at a deeper level, on our ungrounded ways of acting and our reciprocal attribution of these inclinations as standards of correctness. We should stop thinking of this as in conflict with the notion of objectivity, because it is only in terms of it that the notion is possible at all. 


\section{Reply to Blackburn}

Perhaps these reflections will make clear where I think the mistake lies in arguments like Blackburn's, when he points out that "if my community all suddenly started saying that $57+68=5$, this fact does not make me wrong when I continue to assert that it is 125 . I am correct today in saying that the sun is shining and daffodils are yellow, regardless of what the rest of the world says". Obviously there are infinitely many functions that can be denoted by ' $t$ ' which yield 5 as a result for ' $57+68$ '. If we assume the fictional component of Blackburn's example, the community of speakers he is a member of are inclined to take what they do when they obtained 5 out of 57 and 68 as doing the same thing they are doing when they obtain 8 from 5 and 3,14 from 6 and 8, etc. On the other hand, Blackburn is inclined to consider as going on the same way something similar to what we do. Supposedly also, both the community and Blackburn take each other as speaking the same language they speak. For the community, which takes Blackburn as meaning by ' +' the same as they do, Blackburn has made an incomprehensible mistake -one which could force them to revise their hypothesis that he understands ' + ' in the same way as they do. On the other hand, for Blackburn the whole community has made an incomprehensible mistake. He wants to take it as a factual mistake, that is, he interprets them taking his inclinations to use ' + ' as the standard of correctness that gives content to their utterances. But we can start wondering how good his interpretative hypothesis is when it has to interpret the whole community as always giving the wrong answer to ' $57+68$ ', although they happily take each other, when that answer is given, as correctly applying the function denoted by ' + '.

It seems to me that Blackburn's case relies on the very notion of content that is refuted by the rule-following considerations - an inner fact which constitutes the understanding of an expression at a certain moment, according to which each 
subsequent application can be defined as right or wrong, independently of anyone's opinion about this. Once this notion has been given up, there is no sense in which Blackburn's hypothesis (that the community has stopped doing correctly the same thing they were doing before when they used ' + ') can be said to be better than the community's, and the onus is on Blackburn to show how he manages single-handedly to make sense of the distinction -in the language he speaks and takes the community as speaking - between the content of the judgment $57+68=125$ and the other that he believes that $57+68=125$. It is at this point that the asymmetry between the individual and the community appears, provided that my account of how the notion of objectivity arises from the process of reciprocal interpretation is correct. Blackburn argues at the end of his paper that he can, as a putative private linguist, try to make this distinction, ${ }^{7}$ and that I do not deny. What he would need to do is point to the fact that constitutes the difference between his being successful and unsuccessful in this solitary enterprise. ${ }^{8}$

7 Blackburn, op. cit., pp. 299-300.

${ }^{8}$ Crispin Wright has offered in his 'Does Philosophical Investigations I.25860 Suggest a Cogent Argument against Private Language?' (in Subject, Thought and Context, Philip Pettit and John McDowell (eds.), Clarendon Press, Oxford, 1986) an account of how a proposal along the lines of Blackburn's idea would go. According to it, the possibility of a misapplication is given content by the private linguist in terms of "the routine constraints on all scientific theorizing" (p. 239). But as Crispin Wright shows, the success of this proposal depends on the availability of a very peculiar type of theory. This contingency of the possibility of a private language upon the theory available to make sense of it undermines the motivations one may have for believing in such a possibility.

Nevertheless I suspect that Crispin Wright has overestimated the strength of this proposal. The availability of a theory suffices for the possibility of a conflict with observation, but for this conflict to make us discount our observations the theory in question must be a good theory. A good theory must, among other things, have empirical success, that is, accond with a significant number of past observations. But then it seems that in order to be able to describe certain observations as wrong we must rely on the assumption that other observations are right. The only possible ground for this assumption is that the observations which accord with the theory outnumber those which conflict with it. But for this to be a ground it must be previously established that our observations are generally good. It seems to me that this can be made sense of only in terms of a notion of reality that our descriptions can fit or fail to fit, and then the possibility of drawing the 'Seems Right'/'Is Right' 
The notion that the whole community be wrong about what is the case is, of course, not incoherent. But given that the content of their expressions is constituted ultimately in terms of their ungrounded inclinations to act, that they provide the notion of what a state of affairs should be like in order to fulfil a certain content, communal error cannot be made sense of as the abstract possibility that they unnoticedly start applying a rule in a different way from what they used to, but only as the possibility that they would agree in describing as a mistake something which has occurred - a misperception, incomplete or biased information about the state of affairs in question, etc. What is needed is a reason why the best hypothesis to make sense of each other's expressions as content-conveying is not one that minimizes error, but one which takes this particular case as a mistake.

\section{Scepticism}

Let me finish by making some remarks about the relation between this discussion and the issue concerning the sceptical threat against the claim to knowledge. In the picture of content that the rule-following considerations undermine, the subject finds himself in a really awkward situation. The meaning he has attached to a certain expression at a certain moment constitutes a commitment concerning future uses of the expression

distinction operationally depends on the previous availability of a non-operational distinction.

If this is right, the thoughts contained in section 9 of Wright's paper would suffice as a refutation of the possibility of private language. The first of these thoughts is obviously related to the argument I have developed here. "The realist - Wright writes owes an account of the precise mechanism which, quite independently [...] of the private linguist's beliefs, determines the truth values of his statements" (p. 254). The second line of thought has not been pursued in this essay, but, if successful, undermines the coherence of the notion that the private linguist even tries to establish the distinction 'Seems Right'/'Is Right'. The question is "whether there can be such a thing as aiming at a trascendent target: a target such that there is no criterion for saying of any particular shot whether it hits, or is likely to hit, or not, and hitting or missing which can have no consequences for the course of your own or another's future experience" (p. 256). 
if he wants to be faithful to that understanding. But his understanding does not directly compel him to use the expression in a certain way. In fact his most sincere and thoroughgoing attempts to be faithful in his use to that previous understanding can be unsuccessful, because the pattern of correctness for his responses is not constituted by his inclinations. On the contrary, his inclinations must be right against this independent standard.

Knowledge of how things stand in the world is a special case of this situation. States of affairs could be radically different from what we think they are because the patterns that constitute the contents of the judgments that things are thus and so stand in no constitutive relationship to see things as being thus and so. For all the subject knows, all the justification he can obtain for a certain belief is perfectly compatible with its being wrong, and this even after all possible sources of empirical knowledge have been conjured. He finds himself in the same predicament as the private linguist who claims "Well, I believe that this is sensation $S$ again", to whom Wittgenstein replies: "Perhaps you believe that you believe it!"9

The subject's inclinations, that point at which he runs out of further explanations for his responses, could perfectly, for all he can know, be continuously changing, and this in a very clear sense: namely, against the fixed point constituted by the objective pattern of correctness to which he is committed by his understanding of his expressions. This situation is inescapable if every impression of stability can only be grounded on something which is itself nothing but a mere impression of stability. At the end, the whole chain will hang in the air, with no reasonable hope that what is ungroundedly taken as stable agrees with the notion of stability defined by the (forever transcendent) objective standard to which the subject committed himself by his act of understanding. One wants to say that, as a matter

9 Philosophical Investigations $I, \S 260$. 
of fact, grasp of objective standards is usually correct, even though we have no means to ascertain its correctness in particular cases. The mental medium is, after all, utterly transparent. This thought is likely to provide some temporary consolation - until we realize that it begs blatantly the question at issue.

My suggestion here is that the sceptic's success rests on the availability of a notion of content in whose constitution our subjective inclinations have nothing to do. Only this notion could make sense of a doubt beyond empirical doubt, of the possibility that the world is different from what any empirical test could ever show. If this suggestion is correct, then it should be worth investigating whether the picture of objectivity and content suggested in this paper makes the sceptic's victory a bit harder.

That the subject must at some point run out of justifications for his subjective impression of what is the case seems inescapable. But what can be questioned is whether at that point a further justification would be needed, whether the idea makes sense that the ungrounded way of acting on which the whole chain of justifications is based can be continually changing against the fixed point of reference of an independently constituted pattern. If -as the rule-following considerations show - this idea is untenable, then perhaps that the subject runs out of justifications does not mean that the sceptic has won, but that a level has been reached at which no further justification is required, ${ }^{10}$ because it is in terms of that ungrounded

${ }^{10}$ I take this to be the sense of Wittgenstein's remarks that the point at which explanations come to an end is not "an ungrounded presupposition" $(O C \S 110)$ or "a kind of seeing" (OC $\oint 204$ ), but an ungrounded way of acting. A justification is required to ground the claim to objectivity of a (subjective) belief. If we think of the world as an independent real $m$ in whose constitution the subject has nothing to do, the inescapable fact that justifications come to an end implies that the whole chain of justifications hangs in the air. But if at the bottom of the chain what we find is a level at which our ungrounded way of acting constitutes both objectivity and subjectivity as two independent realms, then that we run out of justifications is not a defeat against the sceptic, because when objectivity and subjectivity have not been distinguished yet there is no room for the need of justifications. See On Certainty, $\S \S 110,204,498$, Philosophical Investigations, § 217. 
way of acting that objectivity is constituted, because it is the only fixed point available, against which all change and stability must be measured: the idea of its changing against an independent standard is completely illusory. This is not the place to develop this suggestion, but perhaps at the end of the day we must thank the sceptic for a real achievement: the provision of what is, after all, nothing but a reductio of a wrong picture of objectivity and content via its epistemic implications.

Recibido: 31 agosto 1989. 


\section{RESUMEN}

El trabajo de Zalabardo se ocupa de una de las ideas centrales de Wittgenstein en relación con la noción de seguir una regla y de algunas de las interpretaciones que se han hecho de ella. Toma las interpretaciones de Kripke y Blackburn y muestra por qué considera que son inadecuadas. A su vez, propone una interpretación alternativa.

La idea de Wittgenstein es que si toda regla se puede interpretar de diversas formas, y si para comprobar que la regla se ha aplicado correctamente se requiere a su vez de otra interpetación, la aplicación nunca se podrá justificar. La inclinación del sujeto a aplicar la regla de determinada manera es lo que la legitimaría, borrando así toda diferencia entre seguir una regla correctamente y tener la ilusión de estarla siguiendo, o sea, no habría conductas reglamentadas o guiadas por normas.

Una reacción común para salir de esta dificultad es sostener que la comunidad determina los patrones de corrección y que es en relación con ella que se juzga la inclinación del sujeto. Esta propuesta, según Zalabardo, es insatisfactoria porque nos obligaría a abandonar la noción de objetividad. La dificultad que señala Wittgenstein persiste, ya que la inclinación del sujeto se juzga en términos de la inclinación de los otros. Y, como señala Blackburn, si la comunidad repentinamente altera sus juicios mientras que el sujeto no, entonces el sujeto tendría que estar en lo correcto a pesar de lo que el resto de la comunidad diga. Debemos rechazar cualquier solución en la cual las condiciones de verdad de un juicio dependan de lo que la comunidad acepta.

Kripke, por ejemplo, nos da una explicación de lo que es seguir una regla apelando a la comunidad. Nos ofrece un argumento para mostrar cómo es que la noción de normatividad socava nuestra comprensión de los conceptos intencionales. Argumenta que el hecho de que haya varias hipótesis que son igualmente aptas para interpetar cómo entendió el sujeto cierta expresión en ocasiones pasadas, se debe a que no hay ningún hecho objetivo que nos permita decidir cuál de esas hipótesis es la correcta. Pero, para Zalabardo, este argumento que apunta al problema de la indeterminación de las reglas y no es el problema del que originalmente partió Kripke, a saber, que el discurso que invoca intenciones, entendimiento y significado no es un discurso objetivo - carece de condiciones de verdad. La noción de regla como patrón normativo no existe y, por tanto, no hay diferencia entre seguir nuestras inclinaciones, no seguir regla alguna y seguir una regla. El problema de la indeterminación del significado de las expresiones puede resolverse aceptando que la comunidad determina si una aplicación es correcta o no, pero no resuelve elproblema de qué entendemos por dar significado a una expresión. Si para que el contenido de una expresión sea normativo se requiere que se determine de antemano a qué estado de cosas se refiere y si se muestra que esa determinación no existe, entonces nos quedamos sin 
una noción adecuada de contenido. Kripke pretende solucionar el problema sustituyendo las condiciones de verdad por las condiciones de asertabilidad. Si las adscripciones de contenido ahora dependen de las condiciones de adecuación y las determina quien las adscribe, entonces todos los juicios se convertirían en juicios acerca de él, o en juicios acerca de los miembros de la comunidad y el problema seguiría sin solución. Kripke cuestiona que puedan darse condiciones de verdad para seguir una regla y sostiene que, de cualquier forma, estas condiciones no se necesitan. La objeción de Zalabardo es que Kripke no ofrece ninguna razón para afirmar que dichas condiciones no se necesitan. Kripke tendría que explicarnos qué es lo que atribuimos a un sujeto cuando le atribuimos entendimiento de cierto concepto, ya que nos falta el conocimiento no sólo de las condiciones que nos permitan hacer una determinada atribución, sino también de qué es lo que estamos atribuyendo.

La situación en la que nos encontramos es que para dar cuenta de la diferencia entre meros sonidos y sonidos significativos, o para dar cuenta de la diferencia entre seguir erróneamente una regla o seguir correctamente una regla diferente, no hay ningún hecho objetivo preestablecido, ni nada que esté sucediendo en el fuero interno del sujeto. Para Zalabardo, la única salida posible para alguien que acepta estas dificultades escépticas que amenazan a la idea de contenido, puede encontrarse si admitimos que los miembros de la comunidad -al reconocer las inclinaciones naturales que comparten como grupo- de alguna manera constituyen esos contenidos. Esta será nuestra noción de objetividad: una noción que no es independiente de nuestras maneras naturales de actuar y de que tomemos como patrón de corrección la atribución mutua de esas maneras de actuar. El que interpreta la conducta al interpretarla la establece como conducta reglamentada, esto es, le atribuye al sujeto una noción de lo que la regla exige independientemente de lo que él crea que la regla exige. Si suponemos que el sujeto está siguiendo determinada regla, su conducta será correcta o incorrecta según la conducta que de acuerdo con la regla debería tener. En esta versión, no es posible que los individuos que interpretan la conducta de otro puedan estar sistemáticamente equivocados ya que esto supondría lo que ya se negó: que hay un hecho adicional que ellos podrían captar equivocadamente. En la propuesta de Zalabardo no se excluye que los que interpretan la conducta del otro se puedan equivocar, ya que considera que el proceso interpretativo es recíproco, de manera que al suscitarse un conflicto en las respuestas, cualquiera de ellas puede ser incorrecta.

La concepción de cómo es el mundo también depende, en un nivel más profundo, de nuestras inclinaciones naturales al actuar y de nuestras atribuciones mutuas de esas inclinaciones como patrones de corrección. Nuestro patrón compartido constituye el punto de referencia fijo, que resulta de nuestra interacción interpretativa, y en virtud del cual se define la mismidad, lo que significa la estabilidad y el cambio, es decir, cuándo los objetos tienen la misma propiedad, o cuándo la propiedad del objeto 
cambia. De esta manera, Zalabardo cree poder rebatir el argumento de Blackburn, según el cual un cambio repentino en lo que hace la comunidad no convierte en errónea la conducta del que continúa haciendo lo mismo. El sujeto debería cuestionar la adecuación de su hipótesis interpretativa según la cual la respuesta que los demás dan siempre es falsa a pesar de que ellos creen lo contrario. El problema para Blackburn es que necesita la noción de contenido que justamente ha rechazado el escéptico, es decir, como una noción independiente de todo sujeto, para poder explicar que los demás han dejado de hacer lo que antes hacían.

Zalabardo concluye su trabajo señalando cómo estos resultados, aplicados a la situación que plantea el escéptico - según la cual siempre es posible que el mundo sea diferente de lo que nosotros suponemos- nos llevan a una reducción al absurdo de la noción de contenido que allí está implícita. El escéptico se vale de una noción de contenido independiente de las inclinaciones naturales de los sujetos, cuando es justamente esta noción de contenido la que está en cuestión.

[Salma Saab] 